\title{
urban past
}

This is a pre-print version of a chapter that has been published in the book 'Dynamics of mediatization: institutional change and everyday transformations in a digital age'. Please cite this chapter as:

Van der Hoeven, A. (2017). The mediatization of urban cultural heritage:

Participatory approaches to narrating the urban past. In O. Driessens, G. Bolin, A.

Hepp, S. Hjarvard (Eds.), Dynamics of mediatization: Institutional change and everyday transformations in a digital age (pp. 293-312). London: Palgrave Macmillan.

Arno van der Hoeven

Erasmus Research Centre for Media, Communication and Culture, Erasmus University Rotterdam, the Netherlands

vanderhoeven@eshcc.eur.nl

\begin{abstract}
This chapter examines how the mediatization of cultural heritage enables people to participate in the conservation of the urban past. The ways in which mediatization fosters public involvement in urban heritage conservation will be explored by focusing on three developments: the digitization of heritage collections; the growing attention paid to audience participation by heritage institutions; and the grassroots practices of cultural heritage initiated by citizens. Finally, I discuss how the mediatization of cultural heritage changes the public role of heritage institutions and their professionals. My main argument is that mediatization results in a growing diversity of urban heritage initiatives. However, this process of mediatization feeds into wider developments towards the democratization of cultural heritage.
\end{abstract}




\section{Introduction}

Cities are dynamic places that continuously change and develop. Furthermore, they are centres of creativity, culture and innovation (Glaeser 2011). Heritage plays a vital role in providing a sense of continuity in these dynamic urban environments. This chapter asks how the mediatization of urban cultural heritage enables people to participate in the conservation of the urban past. Various recent heritage policies, such as UNESCO's Recommendation on the Historic Urban Landscape, seek to foster community participation in heritage practices. The active involvement of people in the conservation of urban heritage is particularly relevant in cities, as urban places host a rich diversity of communities with different lifestyles, ethnic backgrounds and cultural interests. As I will argue in this chapter, digital media technologies facilitate the representation of their heritage.

Heritage refers to those aspects from the past that are preserved because they form an essential part of the identities of communities (Graham and Howard 2008; Smith 2006). It provides a temporal grounding to the attachments people have to cities and their diverse communities. In that sense, heritage is about communication (Groote and Haartsen 2008) for the reason that it represents the histories of a place and the values we attribute to the past. Cultural heritage is a key asset that shapes the image of cities and contributes to the ways in which people identify with a place (Paganoni 2015). In fact, while national identities are being challenged by the forces of globalization, identification with cities seems to be growing (Ashworth et al. 2007; Prévélakis 2008). In the context of rapid urbanization, policy makers and researchers are increasingly concerned with finding new ways of preserving urban heritage (Bandarin and vVan Oers 2015).

Various media forms have a vital role in disseminating narratives of cultural heritage (Malpas 2008; Wellington and Oliver 2015; De Groot 2009). Online media, for example, make it possible to share heritage in virtual environments. The advent of the internet in particular has spurred a renewed interest in cultural heritage (Flinn 2007; Van den Broek et al. 2009), providing the impetus for large-scale efforts to digitize all sorts of cultural heritage objects. Online media thus afford unprecedented access to historical material through platforms such as YouTube. Consequently, it is now easier for urban residents to engage with heritage narratives related to their physical surroundings. 
In this chapter, I will argue that mediatization results in the growing diversity of the people who participate in the narration of the urban past. Along with the activities of museums and archives, grassroots heritage initiatives are emerging in virtual spaces such as Facebook groups (Gregory 2015). Meanwhile, existing heritage institutions also come to pay more attention to audience participation. I will explain that, although museums and archives thus change their practices through mediatization, this process is inseparable from other developments in this field. Mediatization feeds into wider developments towards the democratization of cultural heritage. Over the last few decades, there has already been growing attention paid in the heritage sector to questions of participation, cultural diversity and the representation of subaltern voices. These institutional transformations will be discussed in the next section. Subsequently, the ways in which mediatization fosters public involvement in urban heritage conservation will be explored by focusing on three developments: the digitization of heritage collections, the growing attention paid to audience participation by heritage institutions, and the grassroots practices of cultural heritage initiated by citizens. Finally, I discuss how the mediatization of cultural heritage changes the public role of heritage institutions and their professionals.

\section{Institutional Transformations in the Heritage Field}

In defining the mediatization of culture and society, Hjarvard (2013) argues that this involves a duality in which media increasingly affect the operations of various social institutions while also becoming separate social institutions in their own right. Increasingly, institutions such as politics have adapted to what has been defined as a media logic. In very general terms, this means that these institutions have integrated the way media operate in their own practices and pay more attention to questions of communication and publicity. However, the consequences of mediatization vary for different social institutions and fields. Therefore, we need to study the dynamics of mediatization in relation to other socio-cultural developments and cultural spheres. As Hepp (2013: 38) states, "mediatization seeks to capture the nature of the interrelationship between historical changes in media and communication and other transformational processes".

In order to understand how this interrelationship works in the heritage field, I first need to discuss the ongoing development towards the democratization of heritage. Heritage institutions seek to become more inclusive by representing the heritage of different communities. This leads to growing attention being paid to subaltern voices and the heritage of minority groups (Flinn 2007; Smith 2006). The focus on questions of inclusiveness follows on from a recognition that heritage narratives are selective constructions, shaped by present-day concerns (Graham and 
Howard 2008). Thus, heritage always involves a particular orientation to the past, which excludes other perspectives:

Heritage is that part of the past that we select in the present for contemporary purposes, whether these be economic or cultural (including political and social factors), and choose to bequeath to a future, whatever posterity may choose to do with it. (Ashworth et al. 2007: 35)

As this definition shows, heritage narratives are now understood as representations that serve particular goals in the present, such as city marketing or identity building. In other words, heritage narratives are not fixed but are constructed in an active process of remembering through which particular aspects of the past are highlighted (Smith 2006). These critical approaches to heritage have spurred questions about whose voices are represented in heritage narratives and what kinds of perspective are being excluded (Hall 1999).

The democratization of heritage is also manifested in the broadening scope of what is considered to be heritage (Harrison 2013). As existing canons are being questioned, museums and archives are becoming more open to new types of cultural heritage. Mediated cultural forms such as popular music and film, for example, are increasingly archived and exhibited because they are now recognized as vital aspects of the socio-cultural landscape of contemporary society (Moore 2000). Interestingly, the "heritagization" of these popular cultural forms is, in itself, testament to their growing cultural legitimacy. This demonstrates that the mass-produced commercial products of the media and cultural industries are no longer considered to be at odds with the focus on authentic objects in conventional conceptions of heritage (Bennett 2009). As cultural institutions seek to target a broader audience instead of representing solely the interests of elites (Reijnders 2010), they also become more attentive to the heritage of everyday life and popular cultures.

This trend towards democratization has been strengthened by the adoption of media and communication technologies in heritage institutions (Flinn 2007; Pruulmann-Vengerfeldt and Runnel 2011). In the heritage field, there are many experiments that use digital media for more interactive exhibitions, crowdsource inputs and establish online heritage communities (Russo 2012; Snoek et al. 2010). These initiatives foster interactions with audiences and enable their participation in the construction of heritage narratives. Meanwhile, people use social media to 
start their own non-institutional heritage initiatives such as online popular music archives (Baker and Collins 2016) or social networking sites where historic photos are shared (Garduño Freeman 2010).

Arguably, these processes of democratization in the heritage field lead to a wider range of voices being represented. Through the mediums of oral history and digital storytelling (Couldry 2008), for example, people are invited to narrate their personal accounts of historical events. ${ }^{1}$ This could result in a more multi-vocal understanding of the past (Farinosi and Micalizzi 2016; Paganoni 2015), which recognizes the contributions that different communities have made to the ways in which cities have evolved. This is vital, as it is not possible to reduce the history of a city to a single narrative (Massey 1995). Different communities have diverging identifications with cities. Urban places generally differ from rural contexts in their rich diversity of people and cultures. Media enable the representation of the multiple understandings of the past of cities and their relationship to the lives of urban residents.

Researchers studying the ways in which media developments affect the heritage sector have focused predominantly on museums and archives (e.g. Proctor 2010; Pruulmann-Vengerfeldt and Aljas 2011; Verboom and Arora 2013; Wellington and Oliver 2015). This is understandable, as these are important institutions for the presentation and preservation of cultural heritage. However, a consequence of mediatization is that more people can participate in the construction of cultural heritage narratives. Increasingly, all sorts of commercial and grassroots initiatives aim to contribute to the archiving and presentation of cultural heritage (Flinn 2007; Pessach 2008). Examples are popular representations of the past in games, magazines and historical television shows (De Groot 2009). Arguably, Google, with its Google Books and Google Arts projects, is one of the most well-known instances of a commercial organization making digitized cultural heritage available in the public domain. However, there are also many smaller-scale and local initiatives that emerge outside the realm of the classic heritage institutions. Examples are neighbourhood museums, city blogs and cultural entrepreneurs who use new media to present local heritage narratives.

These new heritage activities largely benefit from processes of digitization, in which non-digital original objects are converted to digital representations in the form of a binary code. Finnemann (2014) defines digitization as a set of particular modes of mediatization. It creates new possibilities such as making objects searchable, reproducible and editable. In the digital spatial 
humanities (Roberts 2015), these digital developments are used to enhance research on place. The present chapter contributes to this emerging research by examining how mediatization enables people to participate in the conservation of the urban past.

In so doing, this chapter will discuss professional and grassroots initiatives in various Dutch cities. The examples that will be introduced are drawn from my wider research on urban cultural heritage. For my earlier work on social media and urban heritage (Van der Hoeven 2016), I have conducted a qualitative content analysis on online heritage platforms from four Dutch cities. In the next section, I will start with a discussion of the general trend towards the digitization of urban heritage collections. This is necessary to understand how mediatization enables public involvement in urban heritage conservation.

\section{Digitization of Cultural Heritage Collections}

An important consequence of mediatization is the virtualization of social institutions, which means that institutions become less tied to a specific physical location (Hjarvard 2013). In the heritage field, the digitization of collections plays an important role in this process, making it easier to engage with heritage narratives without actually being present at heritage sites or archives. The advent of the internet, in particular, has contributed to the "virtualization" of urban heritage. In the last decade or so, heritage organizations have made huge efforts to make their collections available in virtual environments. Research conducted in 2013 showed that Dutch heritage institutions estimate that, so far, $28 \%$ of their collections have been digitized (DEN and Enumerate 2014).

Digital heritage collections have several advantages over their analogue equivalents. Of course, digitization is particularly important when original analogue media formats tend to deteriorate (Valtysson 2015). Furthermore, digital heritage objects can be edited, re-used and easily distributed through different media channels. A digital photo, for example, can be manipulated or combined with audio in a video or users can tag its content (Bratteteig 2008; Coyne 2012). Digitization thus gives heritage materials a new life. In virtual spaces, people can comment on these digitized heritage objects, adding personal meanings and memories. Digitization also enables multi-modal presentations, such as combinations of music, speech and moving images (Lundby 2008). Furthermore, digitized heritage collections become more accessible when they can be viewed outside an archive or museum. The availability of cultural heritage in virtual 
spaces thus provides several affordances to both heritage institutions and their audiences. As the Amsterdam Museum states in its business plan:

Next to the duty to preserve and conserve, the museum also has a duty to show the collection, primarily in the museum, but also by showing it extramurally and digitally. An important step was to make the complete collection accessible through the internet. The Amsterdam Museum was the first Dutch museum to do so. As a follow up, a free app was developed in 2011 so that the complete collection can also be retrieved with a mobile phone. ${ }^{2}$

In this way, museums can reach audiences who would otherwise not visit their physical locations. Instead of needing people to come to the museum, heritage becomes accessible from home. Moreover, this enables people who have moved away to explore the heritage of the city where they grew up.

These developments diversify the ways in which the urban cultural heritage of cities is made visible and how people interact with it. As discussed in the introduction of this chapter, cities are dynamic places that continuously develop as history unfolds. The mediatization of urban cultural heritage makes it possible for people to engage with these changes. In Rotterdam, for example, World War II led to the almost complete destruction of the inner city. The author is involved in a multi-media heritage project about the 75 years of reconstruction of the city after the bombings. ${ }^{3}$ In this project, people were invited to share their photos and videos of the reconstruction of Rotterdam, so that these analogue media formats could be digitized. The most interesting material was passed on to the city archive or made visible in the public space through exhibitions in shop windows. The project gave new life to audio-visual materials that otherwise would have remained hidden in the attics of their owners or even disappeared as old videotapes deteriorated over the years. Furthermore, the historical photos exhibited in shop windows were meant to provide inspiration for the future development of these areas.

The mediatization of urban cultural heritage thus makes the past more accessible, albeit within certain legal constraints, as this accessibility is often complicated by copyright regulations (Baker and Collins 2016; Truyen and Waelde 2016). Indeed, in 2015, the archive of the city of Rotterdam took many digitized photos offline after a legal battle with an organization representing the rights of photographers. This temporarily reversed the process of virtualization, 
as users again had to go the physical location of the archive to explore the photo collection. ${ }^{4}$ This example shows that the mediatization of cultural heritage not only depends on the affordances of media but needs to be understood in relation to wider regulatory frameworks.

\section{Audience Participation}

The digitization of cultural heritage, which I discussed above, brings new opportunities for heritage institutions to let their publics participate in the preservation of the urban past. As media are increasingly integrated in the practices of these institutions, their users can take a more active role in constructing and sharing heritage narratives. Hjarvard (2013) argues that the focus on audience involvement and the production of social relations between people is a defining characteristic of how contemporary media operate. As Livingstone (2013: 26) observes about these questions of participation:

The idea of participation has become a compelling topic for public attention, resulting in a clamor of reflexive questioning - is there enough participation in society, should institutions be more participatory, are young people too apathetic, who's listening to citizens' voices, whose voices are going unheard, and what should be done about it?

In the heritage sector, the attention paid to participation fits into long-standing developments towards democratization. Heritage institutions have indeed become more reflexive about the voices that go unheard in their work (Ashworth et al. 2007). The mediatization of cultural heritage could potentially further democratize this work, as there are now more tools with which to actively involve the public. Jenkins (2009) has described this as a participatory culture, which has lower barriers for people to produce and share cultural content by using new media such as social networking sites. Although this could potentially lead to more balanced power relations between heritage institutions and their audiences (Pruulmann-Vengerfeldt and Runnel 2011), in practice the level of participation varies widely.

Writing about participatory practices, Carpentier (2015) distinguishes between minimalist and maximalist forms of participation. In the case of the latter, people get control over the outcome of such practices while professionals retain strong control over the process in the former. I find that participatory practices in this field lean towards minimalist participation, as heritage professionals largely set the boundaries for these projects and bring them into line with an organization's aims. In so doing, they solicit inputs from their publics or facilitate initiatives 
such as digital storytelling and community exhibitions. Users can thus contribute more actively to heritage narratives, albeit within institutional boundaries. Of course, it is also in the interest of heritage institutions to provide opportunities for participation. These institutions are increasingly required by funders to actively involve their audiences (Watson 2007). By working with communities, they can enhance their public relevance and legitimacy.

An interesting example of such a participatory heritage initiative is the re:DDS project, curated by the Amsterdam Museum. This is a pilot project for web archaeology, in which the museum aims to reconstruct a digital city that had its base in Amsterdam. The original digital city, founded in 1993, was one of the first online communities to use the metaphor of a city for its design. ${ }^{5}$ To reconstruct it, the museums asked former "inhabitants" to share memories and search for old servers and hard drives containing relevant information. Furthermore, computer science students have helped to make old digital archives accessible again. This example shows how participation makes it possible to involve the local public, solicit their contributions and thus provide a richer account of the urban past. In so doing, these initiatives give a voice to the diverse communities of cities. At the same time, the museum retains a central role in the execution of the project.

These participatory projects also make it possible to document the intangible heritage values that people attach to urban cultural heritage. Increasingly, heritage institutions invite people to share memories, personal stories or their experiences of particular historic events. On a dedicated website for participatory heritage activities, the Historical Museum of The Hague, for example, asks people from The Hague to share objects that relate to the history of the city. ${ }^{6}$ The photos presented on this website are accompanied with stories about what these objects (e.g. historic newspapers, diaries and ticket stubs) mean to the participants. This fits into the democratization of heritage, as there is increasing attention paid to the ways in which people experience the heritage of cities in their everyday lives (Reijnders 2010). Consequently, heritage institutions no longer focus on merely objects and elites from the distant past but also the meanings that heritage has to urban communities in the present. These are the affective dimensions of heritage, representing how people identify with urban heritage narratives. According to Caswell and Mallick (2014), these emotional meanings are often neglected in official heritage practices, although they carry important information about how the past was experienced. These authors argue that digital participatory projects help to fill such historical gaps by involving community members. 
However, of course, not all urban residents participate in such projects. Inequalities in the physical space can be echoed in the symbolic spaces of heritage initiatives (Morley 2001). In other words, people who live on the margins of cities might also be less likely to become involved in participatory heritage practices. De Kreek (2014) gives an example of this in the "Memory of East" project, which is a local memory website initiated by the Amsterdam Museum where people share stories and memories about the eastern borough of the city. In his study of the content and organizational context of the website, De Kreek (2014) observes that some neighbourhoods are underrepresented. Although the website aimed to involve minority groups, this proved to be difficult in practice:

Although the present group invites anyone to contribute a memory about the far or recent past, not all the people who are reached with this invitation, feel they have something interesting to tell or are insecure about their writing. To deal with this, people are invited to participate in workshops, which is again a threshold for many locals. (De Kreek 2014: 17)

As a consequence, people who did not grow up in Amsterdam East are underrepresented on the website. In another project, which focused on South Asian immigrants' first day in the US, Caswell and Mallick (2014) made a similar finding that limited access to technology was a barrier for working-class immigrants to contribute to the digital archive. Thus, as heritage professionals develop participatory projects, they face the challenge of developing inclusive practices that reflect the diversity of contemporary cities.

\section{Grassroots Heritage Initiatives}

While the previous section focused on participatory projects initiated by established institutions, I will now turn to grassroots initiatives emerging outside the realm of professional organizations. These initiatives benefit from the growing availability of tools for media production. Not only are media more ubiquitous in our everyday lives because of mediatization processes, media users also have more digital technologies at their disposal to produce media content themselves (Rainie and Wellman 2012). As the software and hardware for recording, photo-editing, creating websites, scanning and storing data is now widely available, it is easier for people to archive and share material related to the history of particular cities. This is in 
contrast to previous eras, where the recording of the past was largely the preserve of elites (Garde-Hansen et al. 2009; Haskins 2015).

Indeed, we can observe a wide range of grassroots initiatives that aim to document the urban past. Examples are Facebook groups where old photos of cities are shared, blogs with local memories, and online popular music archives. The local Facebook pages in particular are very popular. Nowadays, almost every city has at least one Facebook group with historical photos, provoking reminiscences and nostalgia in the comment sections. Interestingly, these groups bring cultural heritage to the virtual spaces that people use on a daily basis. In so doing, they make the past of cities available on social media in an accessible manner. Writing about the "Beautiful buildings and cool places Perth has lost" Facebook group, Gregory (2015:24) found that the discussions in the group go beyond mere talk:

[I]n showcasing lost buildings and places from the past, social media such as Facebook enhances both awareness of and collective attachment to the past by facilitating the public expression of emotional responses to the past. Moreover, it helps to generate the social capital needed to mobilise against the destruction of heritage buildings and places.

Similarly, Silberman and Purser (2012) argue that digital technologies enable the construction of "memory communities". Thus, online heritage practices can foster social relations that extend to the physical city. The connections that are formed in online spaces then translate to actual urban encounters. In the case of the abovementioned local memory website in Amsterdam, for example, the online activities lead to walking tours past places discussed on the website.

These grassroots heritage initiatives diversify the narration of the urban past. As the barriers to content production become lower, people without formal training in the heritage field have more opportunities to find an audience by sharing historical material. This can complement the collections of established heritage institutions because grassroots initiatives might raise awareness of hidden or neglected histories. Writing about heritage initiatives in which communities themselves have a central role, Flinn (2007) discusses how these projects document the experiences of, for example, LGBTs, working-class communities and people involved in disappearing occupations. According to Flinn, Stevens and Shepherd, "[M]ost community archives offer an important and empowering assertion of community resistance to 
otherwise exclusionary and (often) marginalizing dominant narratives". These practices can thus lead to a wider representation of heritage themes and voices.

However, grassroots heritage initiatives also face notable sustainability and accessibility challenges. They have to work with less resources than established institutions. This means they generally use generic social media platforms (e.g. Facebook or WordPress) instead of dedicated heritage technologies (Lewi et al. 2015). Furthermore, as these bottom-up heritage projects often rely on a few enthusiasts, their continuation can be at risk when older volunteers are unable to find successors to run them (Baker and Huber 2012). Furthermore, the lack of formal archiving procedures affects the sustainability of projects. Although the informal nature of these initiatives is often their charm, it can lead to a situation where documents and files will no longer be available in the future. This is particularly the case on social media, where archival material and memories are being circulated on platforms that are not specifically designed for that purpose. Baker and Collins (2016) use the term "unintentional archives" for the initiatives that are run by individuals who do not necessarily conceive of their activities as archiving. The researchers discuss the fact that Facebook has limited archival functionality and that newer content usually replaces earlier posted material. Indeed, the design of the medium used for remembering affects how the heritage is presented and what kinds of conversation unfold (Simon 2012). Other challenges that Baker and Collins (2016) identify are a lack of resources to deal with copyright regulations and creators who gradually lose interest in the collection. Although grassroots initiatives diversify the narration of the urban past, these challenges show that they sometimes operate in a precarious position. Nevertheless, more institutional projects can also encounter issues of sustainability, as they often rely on temporary funding.

\section{Urban Cultural Heritage Networks}

In the previous sections, I have discussed the fact that the mediatization of urban cultural heritage is strongly related to several notable developments in this field: more voices can participate in the narration of the urban past, digitized content is being circulated through different media channels, and heritage institutions show increasing concern about questions of participation. In this final section, I will discuss how these developments affect the public role of heritage professionals and how grassroots initiatives relate to more institutional examples.

Museum curators and archivists are important gatekeepers when it comes to engagement with the past. Traditionally, people working in museums and archives are custodians of the heritage 
of cities. However, their authority is challenged in a participatory culture where lay people have more opportunities to share and comment on historical material. In such a culture, people can produce heritage narratives that are not defined and authorized by experts working in established heritage institutions (Silberman and Purser 2012). Moreover, information is no longer contained between the walls of institutions when collections are being digitized (Russo 2012; Verboom and Arora 2013). Hjarvard (2013) helpfully draws upon Bourdieu's field theory to explain how institutions become less autonomous when media affect the internal structure and norms of, for example, the heritage field. As this field is opening up to participation and a wider range of voices, heritage professionals have to redefine their public role and the ways in which they communicate with their audiences (Pruulmann-Vengerfeldt and Runnel 2011). Through new media, they are able to enter into a dialogue with their audiences and facilitate participation and co-creation. As Verboom and Arora (2013) find in a study on the museum blogosphere, "Today, museums still assert their authority, albeit in a different, more personal tone of voice, which may put pressure on their previously 'unassailable voice"”.

I find that heritage professionals increasingly work in a networked structure as a consequence of the mediatization of cultural heritage. In a network, heritage organizations can collaborate with different partners to preserve and present the urban past. Furthermore, in the on- and offline networks of organizations, professionals and the public who participate in heritage practices, the activities of grassroots heritage initiatives and official heritage institutions can coexist. This enables different organizations to connect while maintaining their own organizational identity. This is useful because some grassroots heritage organizations prefer to remain relatively independent from established institutions in order to have more control over their collections (Flinn 2007). Grassroots projects that represent the heritage of specific communities can have aims that are different from those of "official" heritage institutions with a public orientation. Furthermore, some grassroots projects are more informal, as they are driven by the passion of volunteers and focus on the affective connections with the material that is preserved (Baker and Huber 2013). We thus see a range of practices within urban heritage networks that encompass different approaches to a city's past.

However, grassroots heritage initiatives can also benefit from the expertise of museums and archives. Even in a participatory culture, museums and archives are still widely recognized as institutions of authoritative knowledge (Wellington and Oliver 2015). The expertise of heritage professionals on, for example, heritage management and policy remains vital but is 
complemented with a more supportive role (Silberman and Purser 2012). Heritage institutions can function as central hubs of knowledge and expertise within networks. The Historical Museum of The Hague, for example, supports a heritage network that is focused on migration in this city, helping organizations representing migrants to set up their own archival practices, because these smaller bodies often lack the necessary expertise (Caswell and Mallick 2014). ${ }^{7}$

As central hubs in local heritage networks, heritage institutions could provide a platform for the different voices that want to raise awareness of their past. As this chapter has shown, there are an increasing number of heritage initiatives in contemporary cities. However, not all of these voices are being heard. Heritage institutions could connect the "small stories" shared on diverse media platforms to the wider narrative of urban history. Similarly, Silberman and Purser (2012: 14) define the task of heritage professionals as enabling "contemporary communities to digitally (re)produce historical environments, collective narratives and geographical visualizations that cluster individual perspectives into shared forms and processes of remembering". Particularly with the information overload in the contemporary media landscape, heritage professionals can function as gatekeepers who guide their publics to relevant information about the urban past. In so doing, they help to qualify and interpret the plethora of heritage narratives that circulate in the physical and virtual realms of contemporary cities.

\section{Conclusion}

This chapter has been concerned with the relationship between mediatization and urban cultural heritage. The concept of mediatization denotes long-term changes by which social institutions increasingly attune their practices to questions of publicity, media exposure and communication while media institutions themselves also gain a growing influence in society (Hjarvard 2013). As part of these developments, media are increasingly implicated in how cities are experienced and managed (De Lange and De Waal 2013; Koch and Latham 2014). Local governments and institutions use media to foster a sense of place and local belonging and to give cities a distinctive identity (Paganoni 2015). This image of cities is largely constituted by their cultural heritage.

In this chapter, I have discussed several consequences of mediatization for the ways in which people engage with the heritage of cities. First, the digitization of heritage collections renders them more accessible. Once digitized, heritage materials can be distributed through different 
media channels, re-used and edited by the public. Consequently, the engagement with heritage is no longer necessarily embedded in the physical locations of museums and archives. This gives people easy access to, for example, old photos of buildings and neighbourhoods that no longer exist. Particularly in rapidly changing cities, there is an urge to share these digital fragments of the past. Secondly, the focus on user involvement in the contemporary media landscape (Hjarvard 2013) also manifests itself in the field of cultural heritage. Heritage institutions use digital media to let their publics participate in the narration of the urban past. The practitioners working for these institutions are increasingly challenged to develop more inclusive heritage practices that represent the diversity of contemporary cities. Finally, urban communities, in turn, seize on the opportunities of a participatory culture to initiate their own grassroots heritage projects. This allows people who share a certain lifestyle, cultural interest or ethnic background to document their contributions to urban histories.

We can thus observe a growing diversity of initiatives that encompass grassroots, institutional and commercial projects. This leads to a broader representation of urban cultural heritage, as more people now participate in its preservation. In this context, heritage professionals have to redefine their pubic role because they operate in networks where many different people and organizations contribute to the preservation of urban cultural heritage. In their new role, more attention is paid to public engagement and facilitating participatory heritage practices. Heritage institutions thus draw upon various media technologies to give their audiences a more active role in the construction of heritage narratives.

To put it succinctly, these developments show how the mediatization of cultural heritage can enable richer accounts of the urban past. Mediatization proves to be a useful meta-concept for understanding developments in the urban cultural heritage field but has to be examined in relation to wider social forces. The mediatization of urban cultural heritage feeds into ongoing developments towards democratization in the heritage sector. In the last few decades, questions of inclusiveness, participation and representation have been high on the agenda in this field. As media are integrated in the practices of heritage institutions, the focus on audience participation and public engagement is further strengthened. However, even in a participatory culture, the involvement of people is constrained by the technological and socio-economic resources they have at their disposal. This challenges researchers, policy makers and heritage professionals to consider how media can be used in ways that are representative of the diverse heritage of contemporary cities. 


\section{Notes}

1) Oral histories are recorded interviews with people that are conducted with the aim of capturing their subjective experiences of particular historical events (Haskins 2015). Digital storytelling is a way to enable ordinary people to develop short media products (e.g. video or audio or both) about particular personal memories or experiences (Couldry 2008; Lundby 2008).

2) All Dutch quotes have been translated by the author. The business plan was downloaded from

https://www.amsterdammuseum.nl/sites/default/files/ondernemingsplanam_31_01_12 _1.pdf . Accessed: 27 April 2017.

3) See www.rottop.nlwww.digitup.nl . Accessed: 27 April 2017.

4) See http://www.stadsarchief.rotterdam.nl/nieuws/beeldbank-stadsarchief-rotterdamop-zwart . Accessed: 27 April 2017.

5) http://hart.amsterdammuseum.nl/nl/page/33444 . Accessed: 27 April 2017.

6) http://www.mijndenhaag.org/ . Accessed: 27 April 2017.

7) https://www.haagshistorischmuseum.nl/stad-van-aankomst . Accessed: 27 April 2017.

\section{Acknowledgements}

The author would like to thank Joost Groenendijk and Simone Driessen for their comments on earlier versions of this chapter. 


\section{References}

Ashworth, G.J., Brian Graham, and J.E. Tunbridge. 2007. Pluralising pasts: Identity and place in multicultural societies. London: Pluto Press.

Baker, Sarah, and Alison Huber. 2012. Masters of our own destiny: Cultures of preservation at the Victorian Jazz Archive in Melbourne, Australia. Popular Music History 7 (3): 263-282.

Baker, Sarah, and Alison Huber. 2013. Notes towards a typology of the DIY institution: Identifying do-it-yourself places of popular music preservation. European Journal of Cultural Studies 16 (5): 513-530.

Baker, Sarah, and Jez Collins. 2016. Popular music heritage, community archives and the challenge of sustainability. International Journal of Cultural Studies. Advance online publication, March 9, 2016. doi: 10.1177/1367877916637150.

Bandarin, Francesco, and Ron van Oers. 2015. Reconnecting the city: The historic urban landscape approach and the future of urban heritage. Oxford: Wiley-Blackwell.

Bennett, Andy. 2009. "Heritage rock": Rock music, representation and heritage discourse. Poetics37 (5-6): 474-489.

Bratteteig, Tone. 2008. Does it matter that it is digital? In Digital storytelling, mediatized stories, ed. Knut Lundby, 271-283. New York: Peter Lang.

Carpentier, Nico. 2015. Differentiating between access, interaction and participation. Conjunctions. Transdisciplinary Journal of Cultural Participation 2 (2): 7 28.

Caswell, Michelle, and Samip Mallick. 2014. Collecting the easily missed stories: Digital participatory microhistory and the South Asian American Digital Archive. Archives and Manuscripts 42 (1): 73-86.

Couldry, Nick. 2008. Mediatization or mediation? Alternative understandings of the emergent space of digital storytelling. New Media \& Society 10 (3): 373-391. 
Coyne, Richard. 2012. Mosaics and multiples: Online digital photography and the framing of heritage. In Heritage and social media: Understanding heritage in a participatory culture, ed. Elisa Giaccardi, 161-178. London: Routledge.

De Groot, Jerome. 2009. Consuming history: Historians and heritage in contemporary popular culture. London, New York: Routledge.

De Kreek, Mike. 2014. Evolving empowerment in an online community collecting memories of Amsterdam East. Challenges and Solutions. In CIRN Prato Conference 2014, ed. Larry Stillman, and Tom Denison, Centre for Community and Social Informatics, Faculty of IT, Monash University, Monash.

De Lange, Michiel, and Martijn De Waal. 2013. Owning the city: New media and citizen engagement in urban design. First Monday 18 (11).

DEN and Enumerate. 2014. De digitale feiten 2013-2014. Resultaten van de Nederlandse inbreng in Enumerate. The Hague: Stichting Digitaal Erfgoed Nederland.

Farinosi, Manuela, and Alessandra Micalizzi. 2016. Geolocating the past: Online memories after the L'Aquila earthquake. In Memory in a Mediated World, ed. Andrea Hajek, Christine Lohmeier, and Christian Pentzold, 90-110. New York: Palgrave Macmillan.

Finnemann, Niels O. 2014. Digitization: New trajectories of mediatization? In Mediatization of communication, ed. Knut Lundby, 297-321. Berlin, New York: Walter de Gruyter.

Flinn, Andrew. 2007. Community histories, community archives: Some opportunities and challenges. Journal of the Society of Archivists 28: 151-176.

Garde-Hansen, J, Andrew Hoskins, and A Reading. 2009. Introduction. In Save as... digital memories, ed. J Garde-Hansen, Andrew Hoskins, and A Reading, 1-21. New York: Palgrave Macmillan. 
Garduño Freeman, Cristina. 2010. Photosharing on Flickr: Intangible heritage and emergent publics. International Journal of Heritage Studies 16 (4-5): 352-368.

Glaeser, Edward. 2011. Triumph of the city: How our greatest invention makes us richer, smarter, greener, healthier, and happier. New York: Penguin Press.

Graham, Brian J., and Peter Howard. 2008. Heritage and identity. In The Ashgate research companion to heritage and identity, ed. Brian J. Graham and Peter Howard, 1-15. Aldershot: Ashgate.

Gregory, Jenny. 2015. Connecting with the past through social media: The "Beautiful buildings and cool places Perth has lost" Facebook group. International Journal of Heritage Studies 21 (1): 22-45.

Groote, Peter, and Tialda Haartsen. 2008. The communication of heritage: Creating place identities. In The Ashgate research companion to heritage and identity, ed. Brian J. Graham, and Peter Howard, 181-194. Aldershot: Ashgate.

Hall, Stuart. 1999. Unsettling 'the heritage', reimagining the postnation. Whose heritage? Third Text 13 (49): 3-13.

Harrison, Rodney. 2013. Forgetting to remember, remembering to forget: Late modern heritage practices, sustainability and the "crisis" of accumulation of the past. International Journal of Heritage Studies 19: 579-595.

Haskins, Ekaterina V. 2015. Popular memories: Commemoration, participatory culture, and democratic citizenship. South Carolina: University of South Carolina Press.

Hepp, Andreas. 2013. Cultures of mediatization. Cambridge: Polity Press.

Hjarvard, Stig. 2013. The mediatization of culture and society. London: Routledge.

Jenkins, Henry. 2009. Confronting the challenges of participatory culture: Media education for the 21 st century. Cambridge MA: The MIT Press. 
Koch, Regan, and Alan Latham. 2014. Representing and imagining the city. In Cities and social change: Encounters with contemporary urbanism, ed. Ronan Paddison and Eugene McCann, 14-32. London: Sage.

Lewi, Hannah, Andrew Murray, Wally Smith, and Sarah Webber. 2015. Some implications of digital social media for heritage practice. Paper presented at the Australia ICOMOS Conference 2015, Nov 5-8, Adelaide. http://www.aicomos.com/wpcontent/uploads/Some-implications-of-digital-social-media-for-heritage-practice.pdf . Accessed 27 Apr 2017.

Livingstone, Sonia. 2013. The participation paradigm in audience research. The Communication Review 16 (1-2): 21-30.

Lundby, Knut. 2008. Introduction: Digital storytelling, mediatized stories. In Digital storytelling, mediatized stories, ed. Knut Lundby, 1-20. New York: Peter Lang.

Malpas, Jeff. 2008. New media, cultural heritage and the sense of place: Mapping the conceptual ground. International Journal of Heritage Studies 14 (3): 197-209.

Massey, Doreen. 1995. Places and their pasts. History Workshop Journal 39 (1): 182-192.

Moore, Kevin. 2000. Museums and popular culture. London: Cassell.

Morley, David. 2001. Belongings: Place, space and identity in a mediated world. European Journal of Cultural Studies 4 (4): 425-448.

Paganoni, Maria C. 2015. City branding and new media: Linguistic perspectives, discursive strategies and multimodality. Hampshire: Palgrave Macmillan UK.

Pessach, Guy. 2008. [Networked] memory institutions: Social remembering, privatization and its discontents. Cardozo Arts and Entertainment Law Journal 26 (1): 71-149. Prévélakis, Georges. 2008. City museums and the geopolitics of globalisation. In City museums and city development, ed. Ian Jones, Robert R. MacDonald, and Darryl McIntyre, 16-26. Maryland: Alta Mira Press. 
Proctor, Nancy. 2010. Digital: Museum as platform, curator as champion, in the age of social media. Curator: The Museum Journal 53 (1): 35-43.

Pruulmann-Vengerfeldt, Pille, and Agnes Aljas. 2011. Digital cultural heritageChallenging museums, archives and users. Journal of Ethnology and Folkloristics 3 (1): $109-127$.

Pruulmann-Vengerfeldt, Pille, and Pille Runnel. 2011. When the museum becomes the message for participating audiences. Communication Management Quarterly 6 (21): 159179.

Rainie, Lee, and Barry Wellman. 2012. Networked: The new social operating system. Cambridge MA: MIT Press.

Reijnders, Stijn. 2010. Collecting the contemporary in the imagined city. Quotidian 2: $104-110$.

Roberts, Les. 2015. Navigating the "archive city" Digital spatial humanities and archival film practice. Convergence: The International Journal of Research into New Media Technologies 21 (1): 100-115.

Russo, Angelina. 2012. The rise of the 'media museum': Creating interactive cultural experiences through social media. In Heritage and social media: Understanding heritage in a participatory culture, ed. Elisa Giaccardi, 145-157. New York: Routledge.

Silberman, Neil, and Margaret Purser. 2012. Collective memory as affirmation: Peoplecentered cultural heritage in a digital age. In Heritage and social media: Understanding heritage in a participatory culture, ed. Elisa Giaccardi, 13-29. New York: Routledge.

Simon, Roger I. 2012. Remembering together: Social media and the formation of the historical present. In Heritage and social media: Understanding heritage in a participatory culture, ed. Elisa Giaccardi, 89-106. New York: Routledge. 
Smith, Laurajane. 2006. Uses of heritage. London: Routledge.

Snoek, Cees G.M., Bauke Freiburg, Johan Oomen, and Roeland Ordelman. 2010. Crowdsourcing rock n' roll multimedia retrieval. In Proceedings of the 18th ACM international conference on Multimedia, 1535-1538, ACM, New York.

Truyen, Frederik, and Charlotte Waelde. 2016. Copyright, cultural heritage and photography: A gordian knot? In Cultural heritage in a changing world, ed. Karol J. Borowiecki, Neil Forbes, and Antonella Fresa, 77-96. Springer.

Valtysson, Bjarki. 2015. From policy to platform: The digitization of Danish cultural heritage. International Journal of Cultural Policy, advance online publication, 14 Sept 2015. Doi:10.1080/10286632.2015.1084300.

Van den Broek, Andries, Jos de Haan, and Frank Huysmans. 2009. Cultuurbewonderaars en beoefenaars. Trends in cultuurparticipatie en mediagebruik [Digging culture and doing culture. Trends in cultural participation and media use]. Den Haag: Sociaal en Cultureel Planbureau.

Van der Hoeven, Arno. 2016. Urban memories on social media: Remembering, sharing and mapping. Paper presented at the annual conference of the International Association for Media and Communication Research: Memory, Commemoration and Communication, July 27-31 2016, University of Leicester, United Kingdom.

Verboom, Jessica, and Payal Arora. 2013. Museum 2.0: A study into the culture of expertise within the museum blogosphere. First Monday 18 (8).

Watson, Sheila. 2007. Museums and their communities. London, New York: Routledge.

Wellington, Shannon, and Gillian Oliver. 2015. Reviewing the digital heritage landscape: The intersection of digital media and museum practice. In The international handbooks of museum studies: Museum practice, ed. Conal McCarty, 577-598. Chichester: Wiley. 